\title{
Putative Pre- and Postsynaptic ATP-Sensitive Potassium Channels in the Rat Substantia Nigra in vitro
}

\author{
Alison E. Watts, Gareth A. Hicks, ${ }^{a}$ and Graeme Henderson \\ Pharmacology Department, School of Medical Sciences, University of Bristol, University Walk, Bristol BS8 1TD, UK
}

Pre- and postsynaptic adenosine $5^{\prime}$-triphosphate-sensitive potassium (ATP-K ${ }^{+}$) currents were studied using whole-cell recordings from substantia nigra zona compacta "principal" neurons in midbrain slices. The GABA $_{A}$ and $\mathrm{GABA}_{B}$ receptor-mediated synaptic potentials were unaffected by the ATP-K+ channel inhibitor glibenclamide $(30 \mu \mathrm{M})$ or by the opener diazoxide $(500 \mu \mathrm{M})$, indicating that ATP-K ${ }^{+}$ channels on GABA-ergic terminals are not active, nor can they be activated pharmacologically, under control conditions. However, application of a glucose-free solution to reduce intracellular ATP levels caused a reduction of the GABA $_{B}$ IPSP in all neurons. This was substantially reversed by the sulfonylurea inhibitor tolbutamide $(300 \mu \mathrm{M})$ in $50 \%$ of the neurons tested. The reduction of the $\mathrm{GABA}_{\mathrm{B}}$ IPSP was a presynaptic effect since postsynaptic hyperpolarizations induced by the $\mathrm{GABA}_{\mathrm{B}}$ receptor agonist baclofen (10 $\mu \mathrm{M})$ were unaffected by glucose-free solutions. Diazoxide $(500 \mu \mathrm{M})$ induced a slowly developing hyperpolarization or outward current in $64 \%$ of principal neurons, which was tolbutamide- $(\mathbf{1 0 0}-\mathbf{3 0 0} \mu \mathrm{M})$ or glibenclamide- (30 $\mu \mathrm{M})$ sensitive. In contrast, the $\mathrm{GABA}_{\mathrm{B}}$ receptor agonist baclofen $(30 \mu \mathrm{M})$ induced a rapid hyperpolarization or outward current in all neurons tested that was unaffected by tolbutamide ( $300 \mu \mathrm{M})$. Although both the diazoxide-induced current and the baclofen-induced current were inhibited by $\mathrm{Ba}^{2+}(300 \mu \mathrm{M})$, the currents elicited by diazoxide and baclofen summated. The reversal potential for the diazoxide-induced current was also less negative than that for baclofen, which was close to $E_{K}$. In the presence of intracellular cesium, diazoxide induced a tolbutamide-sensitive inward current in a proportion of neurons, indicating that it has other actions in addition to activating a potassium current. Our results suggest that functional ATP-K+ channels exist both pre- and postsynaptically in the $S N$, where they modulate the activity of principal neurons. They are different to the potassium channels activated by the $\mathrm{GABA}_{B}$ receptor agonist baclofen.

[Key words: substantia nigra, ATP sensitive, potassium channel, sulfonylurea, glibenclamide, tolbutamide, diazoxide, baclofen]

Received Aug. 10, 1994; revised Nov. 1, 1994; accepted Nov. 9, 1994.

G.A.H. held a Glaxo Research Scholarship. This work was supported by the MRC.

Correspondence should be addressed to Graeme Henderson at the above address.

a Present address: Vollum Institute, Oregon Health Sciences University, Portland, $O R$.

Copyright (C) 1995 Society for Neuroscience 0270-6474/95/153065-10\$05.00/0
The substantia nigra (SN) contains a high density of high-affinity, tritiated- ${ }^{3} \mathrm{H}$-glibenclamide binding sites (Mourre et al., 1989, 1990; Treherne and Ashford, 1991). By combining receptor autoradiography and specific neuronal lesions, we have shown that these binding sites are located primarily on striatonigral terminals in SN zona reticulata (Hicks et al., 1994a). Glibenclamide and other sulfonylureas inhibit ATP-K ${ }^{+}$channels (for review see Edwards and Weston, 1993), so the presence of high-affinity ${ }^{3} \mathrm{H}-$ glibenclamide binding sites has generally been assumed to indicate the presence of ATP-K ${ }^{+}$channels. However, this may not be entirely correct. Evidencc from insulin-secreting cell lines suggests that sulfonylurea receptors and ATP-K ${ }^{+}$channels can exist as independent proteins (Khan et al., 1993) requiring $\mathrm{Mg}^{2+}$ to interact (Lee et al., 1994). Furthermore, sulfonylurea drugs have been shown to inhibit other types of $\mathrm{K}^{+}$channels (Reeve et al., 1992; Crépel et al., 1993). Thus, in order to identify ATP$\mathrm{K}^{+}$channels unequivocally, it is essential that autoradiographical results are confirmed by functional studies examining the characteristic pharmacological responses of $\mathrm{ATP}-\mathrm{K}^{+}$channels to channel activators such as diazoxide and to sulfonylurea inhibitors.

Both pre- and postsynaptic ATP-K ${ }^{+}$channels have been described previously in SN. Biochemical studies suggested that the release of the inhibitory neurotransmitter $\gamma$-aminobutyric acid (GABA) from terminals within the $\mathrm{SN}$ may be under the control of ATP-K ${ }^{+}$channels (Amoroso et al., 1990; Schmid-Antomarchi et al., 1990). However, neurochemical studies cannot discriminate between GABA release from intrinsic, inhibitory interneurons and rclcase from striatonigral terminals, nor can it discriminate between $\mathrm{GABA}$ released onto $\mathrm{GABA}_{\mathrm{A}}$ receptors from that released onto $\mathrm{GABA}_{B}$ receptors.

SN zona compacta neurons exhibit a postsynaptic hyperpolarization following reduction of intracellular ATP (Häusser et al., 1991; Röper and Ashcroft, 1993), metabolic poisoning (Röper and Ashcroft, 1993) or application of glucose-free solutions (Röper et al., 1990a). Diazoxide activates ATP-K ${ }^{+}$channels in SN zona reticulata neurons (Schwanstecher and Panten, 1993), although another ATP- $\mathrm{K}^{+}$channel opener, levcromakalim, is without effect on zona compacta neurons (Hicks and Henderson, 1992; but see also Häusser et al., 1991). Single ATP-K ${ }^{+}$channels of $65 \mathrm{pS}$ conductance have been recorded from dissociated SN neurons (Röper et al., 1990a) and of $71 \mathrm{pS}$ in reticulata neurons (Schwanstecher and Panten, 1993).

The superfamily of inhibitory $G$ protein-coupled receptors, which includes $G A B A_{B}$, and dopamine $D_{2}$ receptors, are coupled to an inwardly rectifying potassium channel $\left(\mathrm{I}_{\mathrm{K}(\mathrm{IR})}\right.$, North, 1989). When two or more of these receptor types are present in the same neuron, they activate the same set of potassium channels 
(North and Williams 1985). It has previously been postulated that the ATP- $\mathrm{K}^{+}$channel is also activated by this superfamily of receptors, since the channel appeared to be coupled to GA$\mathrm{BA}_{\mathrm{B}}$ and dopamine $\mathrm{D}_{2}$ receptors (Röper et al., 1990b). However, this finding has been disputed (Hicks and Henderson, 1992).

We have used the whole-cell patch clamp technique to determine whether diazoxide can activate pre- and/or postsynaptic ATP- $\mathrm{K}^{+}$channels in the SN, i.e., ATP-K ${ }^{+}$channels located either on GABA-ergic nerve terminals innervating $\mathrm{SN}$ zona compacta neurons, or on the compacta neurons themselves. We also compared the postsynaptic actions of diazoxide and the GA$\mathrm{BA}_{\mathrm{B}}$ receptor agonist baclofen in order to determine if they are coupled to the same potassium channels.

Preliminary accounts of these results have been presented (IIicks et al., 1994b; Watts ct al., 1994).

\section{Materials and Methods}

Tissue preparation. Male Wistar rats (14-28 d postnatal) were killed by a blow to the thorax and cervical dislocation. The scalp and skull were removed and the brain excised. A block of tissue containing the substantia nigra was mounted caudal surface uppermost, in the chamber of a Vibratome containing ice-cold artificial cerebrospinal fluid (ACSF). Coronal sections, $400 \mu \mathrm{m}$ thick, were cut through the caudorostral extent of the SN and stored in oxygenated ACSF at room temperature until used. Slices were cut in half down the midline and a half-slice was placed in the recording chamber (volume $500 \mu \mathrm{l}$ ), held in place by a nylon mesh and perfused with oxygenated ACSF at $30^{\circ} \mathrm{C}$, flowing at $2 \mathrm{ml} / \mathrm{min}$. This solution contained (mM) NaCl 126, KCl 2.5, $\mathrm{NaH}_{2} \mathrm{PO}_{4}$ $1.24, \mathrm{MgCl}_{2} 1.3, \mathrm{CaCl}_{2} 2.4, \mathrm{NaHCO}_{3} 26$, glucose 10 , saturated with $95 \% \mathrm{O}_{2} / 5 \% \mathrm{CO}_{2}$

Whole-cell recording. The slice was viewed under a dissection microscope, with illumination from below, which allowed identification of the SN zona compacta as a semilucent band between the less luminescent SN zona reticulata and the dark fibers of the medial lemniscus. Whole-cell recordings were made with electrodes that were not fire polished or coated with Sylgard. Pipettes were filled with a solution of the following composition (mM); $\mathrm{K}$ gluconate $140, \mathrm{MgCl}_{2} 2, \mathrm{CaCl}_{2} 1$, ethylene glycol-bis( $\beta$-aminoethylether) $N, N, N^{\prime}, N^{\prime}$-tetraacetic acid (EGTA) $10, \mathrm{~K}_{2}$ ATP 0.1 or 2 ; NaGTP 0.1, HEPES $10, \mathrm{pH} 7.3$ with KOH. For experiments using cesium as the major cation, $\mathrm{K}$-gluconate was replaced with $\mathrm{Cs}$ gluconate or $\mathrm{CsCl}$, and $\mathrm{pH}$ adjusted with $\mathrm{CsOH}$. Where $\mathrm{CsCl}$ electrodes were used, bicuculline methiodide (BMI; $30 \mu \mathrm{M}$ ) was added to the bathing solution to suppress the large inward currents due to spontaneous IPSCs. Adenosine 5 ' diphosphate (ADP, $0.1 \mathrm{~mm}$ ) and guanosine $5^{\prime}$ diphosphate (GDP; $0.1 \mathrm{~mm}$ ) were also added to the pipette solution in some experiments. Gluconate ions produced a tip potential of 5-6 mV, which has been accounted for in the results presented. Electrode resistance was 5-6 M $\Omega$ when filled with this solution and intracellular free $\mathrm{Ca}^{2+}$ concentration was calculated to be approximately 10 $\mathrm{nM}$. Electrodes were guided visually into the region of the $\mathrm{SN}$ zona compacta and whole-cell recordings made using the "blind-patch" method as described previously (Hicks and Henderson, 1992). Membrane potential or voltage clamp recordings were made using an Axoclamp 2A or Axopatch 1B amplifier, respectively, and recorded on chart paper, analog tape, and computer (pCLAMP or DEMPSTER programs) for subsequent analysis.

Synaptic potentials. Bipolar stimulating electrodes (Tefion-coated platinum/iridium wire with tip diameter $0.05 \mathrm{~mm}$ ) were placed in the slice in the ventrolateral half of the SN zona reticulata (approximately perpendicular to the medial lemniscus), and square wave constant-voltage pulses (0.1-0.3 msec duration) were applied. To evoke $\mathrm{GABA}_{\mathrm{B}}$ receptor-mediated synaptic potentials, repeated pulses $(10-100 \mathrm{~Hz})$ were applied in trains of $100-200 \mathrm{msec}$ duration at $0.015 \mathrm{~Hz}$. The amplitude and duration of the pulses were adjusted to give submaximal $(60-70 \%)$ synaptic responses.

Intracellular levels of ATP. The resting level of intracellular ATP is thought to be in the millimolar range, so that ATP- $\mathrm{K}^{+}$channels are strongly inhibited under normal cellular conditions (Ohno-Shosaku and Yamamoto, 1992). The ability of diazoxide and sulfonylurea drugs to bind to the ATP-K ${ }^{+}$receptor depends on the level of intracellular ATP (Schwanstecher et al., 1991). Diazoxide opens ATP-K ${ }^{+}$channels in the presence of $0.3 \mathrm{~mm}$ ATP, but is ineffective with $5 \mathrm{mM}$ ATP (Trube et al., 1986). Thus, the interaction between intracellular nucleotides and drugs acting at the ATP- $\mathrm{K}^{+}$channel may be an important factor in determining the effectiveness of drugs applied to modulate this channel. Therefore, for the study of presynaptic ATP- $\mathrm{K}^{+}$channels, $2 \mathrm{~mm}$ ATP was used in the pipette solution in an attempt to minimize any effects of diazoxide or glucose-free solutions on the postsynaptic neurons, whereas for the postsynaptic studies, $0.1 \mathrm{~mm}$ intracellular ATP was used in the pipette solution in an attempt to lower intracellular ATP and, thus, maximize the possible postsynaptic effects of diazoxide. In addition, guanosine $5^{\prime}$ triphosphate (GTP, $0.1 \mathrm{~mm}$ ) was included in the pipette solution to facilitate G-protein activation since activation of ATP$\mathrm{K}^{+}$channels may involve G-protein coupling (Zini et al., 1993; Terzic et al., 1994).

Drugs. Drugs were applied by superfusion; complete exchange of the solution in the recording chamber took $2 \mathrm{~min}$. The drugs used were 6-cyano-7-nitroquinxaline-2,3-dione (CNQX), D-2-amino-5-phosphonovaleric acid (AP5), and 2-hydroxy saclofen (gifts of Tocris Neuramin, UK), ( \pm )-baclofen (Research Biochemicals, Inc.), bicuculline methiodide, diazoxide, glibenclamide, and tolbutamide (Sigma, UK). Stock solutions ( $10 \mathrm{~mm}$ or $100 \mathrm{~mm}$ ) of the excitatory amino. acid and GABA receptor ligands were prepared in distilled water and stored at $4^{\circ} \mathrm{C}$ [except CNQX, which was dissolved in either dimethyl sulfoxide (DMSO) or $0.1 \mathrm{M} \mathrm{NaOH}$ ]. Other drugs were prepared daily from solid and stored at $4^{\circ} \mathrm{C}$ until used. Diazoxide and tolbutamide were prepared as $100 \mathrm{~mm}$ solutions in $0.3 \mathrm{M} \mathrm{NaOH}$. When diluting these to give the final concentration of drug in the bathing solution, an equal volume of $0.3 \mathrm{M}$ $\mathrm{HCl}$ was added to the ACSF to compensale the small change in $\mathrm{pH}$, a procedure that resulted in insignificant changes in the concentration of $\mathrm{NaCl}$ in the ACSF. Glibenclamide was prepared as a $10 \mathrm{~mm}$ solution in $5 \%$ DMSO and $20 \mathrm{~mm} \mathrm{NaOH}$, and no $\mathrm{pH}$ compensation was made.

Statistics. Numerical data are expressed as the mean \pm standard error of the mean. Statistics cited represent the $p$ value gained using a Student's $t$ test for paired or unpaired data. Differences were considered significant if $p<0.05$.

\section{Results}

\section{Identification of principal neurons}

Whole-cell recordings were made from a total of 104 neurons in the SN zona compacta, which had electrophysiological characteristics similar to those described previously for nigral neurons in in vitro midbrain slice preparations (Lacey et al., 1989; Yung et al., 1991; Nedergaard and Greenfield, 1992). The majority of neurons observed $(85 \%)$ had the characteristics of "principal neurons" and are presumed to be the dopaminergic neurons that are located within the SN zona compacta and form the major part of the nigrostriatal pathway. Other neurons with the previously described "secondary" and "phasic" characteristics were also observed but were not included in this report.

\section{Characterization of synaptic inputs}

To examine evoked synaptic potentials, postsynaptic ncurons were hyperpolarized to membrane potentials between -55 and $-70 \mathrm{mV}$ by injection of negative direct current. This resulted in cessation of spontaneous action potential firing, and subsequent evoked synaptic responses were subthreshold for action potential initiation.

Single-pulse stimulation within the zona reticulata produced a fast compound synaptic response. In some neurons, this consisted of both depolarizing and hyperpolarizing phases. In others, the response was almost purely depolarizing or purely hyperpolarizing. In the majority of neurons, the compound synaptic response was made up of three superimposed components. These could be distinguished pharmacologically as AMPA-, NMDA-, and $\mathrm{GABA}_{\mathrm{A}}$ - receptor-mediated synaptic potentials by the addition of CNQX $(2-10 \mu \mathrm{M})$, AP5 $(30 \mu \mathrm{M})$, and bicuculline $(10-30 \mu \mathrm{M})$. The $\mathrm{GABA}_{\mathrm{A}}$ receptor-mediated inhibitory postsynaptic potential (IPSP) was isolated pharmacologically in 25 neurons. In all neurons tested, the addition of the excitatory amino 
CNQX 10 $\mu \mathrm{M} \&$ AP5 $30 \mu \mathrm{M}$

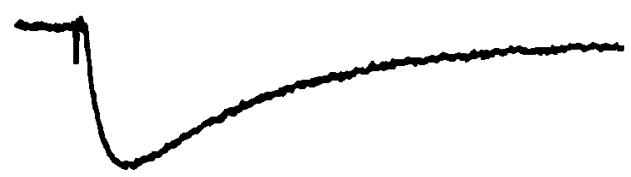

+ Bicuculline 30 $\mu \mathrm{M}$

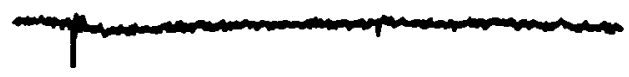

Wash

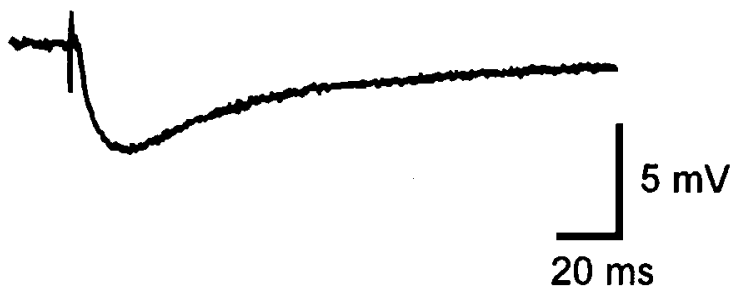

CNQX 10 $\mu M$ \& AP5 30 $\mu M$

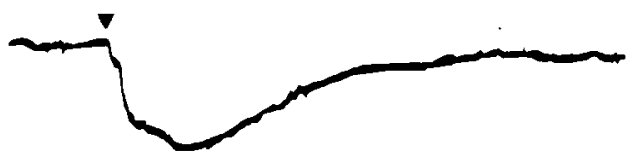

+ Bicuculline 30 $\mu \mathrm{M}$

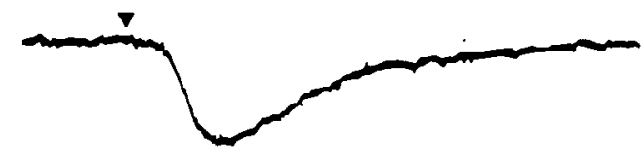

+ CGP 55845A 300nM

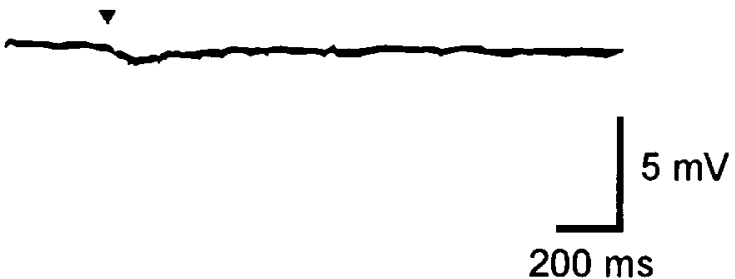

Figure 1. Inhibitory postsynaptic potentials. $A, \mathrm{SN}$ zona compacta neuron hyperpolarized to $-63 \mathrm{mV}$ with direct current injection. In the presence of CNQX $(10 \mu \mathrm{M})$ and AP5 $(30 \mu \mathrm{M})$, a single stimulus evoked a hyperpolarizing postsynaptic potential. This was mediated by GABA receptors since addition of bicuculline $(30 \mu \mathrm{M})$ strongly inhibited the IPSP. The effect was partially reversed upon washout. $B$, Neuron hyperpolarized to $-61 \mathrm{mV}$ using direct current injection. A train of stimuli $(100 \mathrm{~Hz}$ for $100 \mathrm{msec}$, beginning at the point indicated by the arrowhead $)$ evoked a biphasic hyperpolarizing synaptic response in the presence of CNQX $(10 \mu \mathrm{M})$ and AP5 $(30 \mu \mathrm{M})$. The early phase was inhibited by the subsequent addition of bicuculline $(30 \mu \mathrm{M})$. The remaining slow, long-lasting IPSP was mediated by $\mathrm{GABA}_{\mathrm{B}}$ receptors as shown by its blockade by the selective $\mathrm{GABA}_{13}$ receptor antagonist CGP 55845A (300 nM). Stimulus artifacts have been removed to allow a clear view of the IPSP. In both $A$ and $B$, each trace is the average of at least four individual traces of synaptic potentials evoked consecutively in the same neuron.

acid receptor antagonists CNQX and AP5 (10 $\mu \mathrm{M}$ and $30 \mu \mathrm{M}$, respectively, $n=25$ ) left a single hyperpolarizing component (Fig. 1A). It was in the hyperpolarizing direction since gluconate was the major intracellular anion, and reversed polarity at -83 $14 \mathrm{mV}$ (mean $\_\mathrm{SEM}, n=4$ ). The calculated chloride equilibrium potential, $E_{\mathrm{Cl}}$, was $-81 \mathrm{mV}$. The kinetic parameters of the $\mathrm{GABA}_{\mathrm{A}}$ receptor-mediated IPSP were measured in 12 neurons. The mean time to onset was $2.3 \pm 0.3 \mathrm{msec}$, the time from onset to peak amplitude was $10.7 \pm 0.1 \mathrm{msec}$, and the half time of decay was $47 \pm 3 \mathrm{msec}$. The peak amplitude was

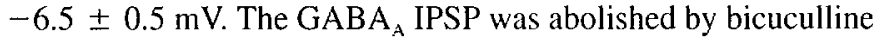
( $30 \mu \mathrm{M}, n=4$; Fig. $1 A$ ). The effects of bicuculline were only partially reversed after washing out the drug for $20 \mathrm{~min}$.

Application of a train of stimuli (sec Materials and Methods) in the presence of CNQX $(10 \mu \mathrm{M})$ and AP5 $(30 \mu \mathrm{M})$ resulted in a biphasic hyperpolarizing synaptic response $(n=29$; Fig. $1 B)$ in which a long duration $\mathrm{GABA}_{B}$ IPSP followed the rapid GA$\mathrm{BA}_{\mathrm{A}}$ IPSP. The $\mathrm{GABA}_{\mathrm{B}}$ component of the response could then be isolated from the $\mathrm{GABA}_{\mathrm{A}}$ component by the addition of bicuculline $(30 \mu \mathrm{M}, n=18)$. The $\mathrm{GABA}_{\mathrm{B}}$ IPSP reversed polarity at $-106 \pm 2 \mathrm{mV}(n=3$; calculated potassium equilibrium potential, $E_{\mathrm{K}},-108 \mathrm{mV}$ ). It had a mean time to onset of $81 \pm$
$8 \mathrm{msec}$, a time from onset to peak amplitude of $246 \pm 11 \mathrm{msec}$, and a half-time of decay of $355 \pm 22 \mathrm{msec}$. The mean amplitude was $-9.2 \pm 0.8 \mathrm{mV}$. This slow, long-lasting synaptic potential was inhibited by the $\mathrm{GABA}_{\mathrm{B}}$ receptor-selective antagonists 2-hydroxy saclofen (100-300 $\mu \mathrm{M}, n=3)$ or 3- $N$-[1-(S)-(3,4dichlorophenyl)ethyl]amino-2-(s)-hydroxy-propyl-P-benzyl phosphinic acid (C.GP 55845A, $300 \mathrm{~nm}, n=1$; Fig. 1B).

\section{Presynaptic ATP- $K^{+}$channels}

The level of ATP in the pipette solution was $2 \mathrm{~mm}$ during this set of experiments.

Diazoxide. The ATP- $\mathrm{K}^{+}$channel opener diazoxide $(500 \mu \mathrm{M})$ applied for up to $15 \mathrm{~min}$ either produced no change in four of five cells, or a reduction ( $34 \%$ in one of five cells) in the am-

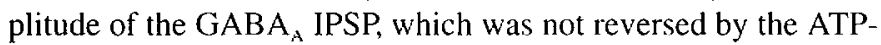
$\mathrm{K}^{-}$channel inhibitor tolbutamide $(300 \mu \mathrm{M})$ but did recover upon washout. Similarly, diazoxide $(500 \mu \mathrm{M})$ produced either no change (in five of six cells) or a tolbutamide-insensitive reduction ( $40 \%$ in one of six cells) in the amplitude of the $\mathrm{GABA}_{\mathrm{B}}$ receptor-mediated IPSP when applied for up to $15 \mathrm{~min}$. Diazoxide applied for this duration did induce postsynaptic effects (see below). Glibenclamide ( $30 \mu \mathrm{M}$ ), applied alone for periods of up 
to $10 \mathrm{~min}$, produced no change in the amplitude or duration of the $\operatorname{GABA}_{\mathrm{A}}(n=4)$ or $\mathrm{GABA}_{\mathrm{B}}(n=5)$ receptor-mediated IPSPs. Thus, under our standard in vitro brain slice recording conditions the putative presynaptic ATP-K ${ }^{+}$channels on GABAergic nerve terminals (Hicks et al., 1994a) do not open (deduced from the lack of effect of the ATP-K ${ }^{+}$channel inhibitor glibenclamide) nor could they be opened by diazoxide.

Glucose-free solution. One explanation for the lack of effect of diazoxide on GABA-ergic IPSPs is that in the GABA-containing nerve terminals the intracellular ATP concentration was high enough to prevent opening of ATP-K ${ }^{+}$channels by diazoxide. In order to reduce the intracellular ATP concentration within the GABA-ergic nerve terminals to levels at which the ATP-K ${ }^{+}$ channels could open spontaneously, we perfused nigral slices with a glucose-free solution. Removal of glucose from the bath ing solution for up to $20 \mathrm{~min}$ did not alter the amplitude or

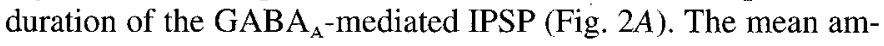
plitude of the IPSP was $-5.9 \pm 0.7 \mathrm{mV}$ in the presence of glucose, and $-6.0 \pm 0.7 \mathrm{mV}$ in the absence of glucose $(n=$ 12). In contrast, removal of glucose from the bathing solution for 15-25 min produced a gradual reduction in the amplitude of the $\mathrm{GABA}_{\mathrm{B}}$-mediated IPSP from $-8.1 \pm 0.9 \mathrm{mV}$ to $-5.6 \pm$ $0.9 \mathrm{mV}$ (30.2 $\pm 4.5 \%$ reduction, $n=12, p<0.005$, paired $t$ test; Fig. $2 B$ ). The reduction in $\mathrm{GABA}_{\mathrm{B}}$ IPSP amplitude was fully reversed when glucose was reapplied $(-8.6 \pm 1.5 \mathrm{mV}, n$ $=8$ ). The reduction of $\mathrm{GABA}_{\mathrm{B}}$ IPSP amplitude would appear to be mediated by a presynaptic reduction in GABA release since (1) it was not associated with any consistent changes in postsynaptic input resistance or membrane potential, and (2) the postsynaptic hyperpolarization produced in principal neurons by bath application of the $\mathrm{GABA}_{\mathrm{B}}$ receptor agonist baclofen (10 $\mu \mathrm{M}$, producing $90 \%$ of maximum response) was unchanged in the absence of glucose (Fig. $2 C$ ). In 10 neurons the mean hyperpolarization produced by baclofen $(10 \mu \mathrm{M})$ in the presence of glucose was $-11 \pm 1 \mathrm{mV}$, and, on reapplication to the same neurons after superfusion with a glucose-free solution for 15$20 \mathrm{~min}$, it was $-10 \pm 1 \mathrm{mV}$.

Tolbutamide $(300 \mu \mathrm{M})$ was tested for its ability to reverse the reduction of the $\mathrm{GABA}_{\mathrm{B}}$-mediated IPSP in glucose-free solutions. In six neurons, the inhibition was rapidly reversed by between $31 \%$ and $100 \%$ (mean reversal of $80 \pm 11 \%, n=6$; Fig. $2 B$ ). In another six neurons, tolbutamide did not reverse the effect of glucose-free solutions. In these cases, however, the IPSP amplitude returned to control levels when glucose was reapplied. These results show that, although the ATP-K $\mathrm{K}^{+}$channel opener diazoxide is without effect on IPSPs, lowering of ATP levels in synaptic terminals does modulate $\mathrm{GABA}_{\mathrm{B}}$-mediated synaptic transmission. In $50 \%$ of cases this appears to be by opening ATP-K $\mathrm{K}^{+}$channels on synaptic terminals.

\section{Postsynaptic ATP-K $K^{+}$channels}

The effect of diazoxide upon principal neurons was investigated using both voltage clamp and membrane potential recordings. The concentration of ATP in the pipette solution was $0.1 \mathrm{~mm}$, and extracellular glucose was $10 \mathrm{mM}$. In some experiments, 0.1 $\mathrm{mM}$ ADP and GDP were included in the pipette solution, in addition to the standard $0.1 \mathrm{mM}$ ATP and GTP, to provide a supply of nucleotides necessary for G-protein and ATP-K ${ }^{+}$channel function. However, responses to diazoxide were comparable either with $(n=7)$ or without $(n=10)$ ADP and GDP in the pipette, so data have been combined.

Neurons had an input resistance of $281 \pm 15 \mathrm{M} \Omega$ and re- quired injection of $-127 \pm 8 \mathrm{pA}$ of current to hold them at $-65 \mathrm{mV}(n=36)$. Diazoxide $(500 \mu \mathrm{M})$ induced an outward current in 17 of 29 neurons under voltage clamp $(59 \%)$, or a hyperpolarization in 16 of $23(69 \%)$ of neurons in current clamp (overall, 64\%). The response developed very slowly over $10-$ $15 \mathrm{~min}$, reaching $-5.0 \pm 0.5 \mathrm{mV}$ in current clamp $(n-15$; Fig. $3 A$ ) or $108 \pm 18$ pA under voltage clamp $(n=17$; Fig. $3 B$ ). The diazoxide-induced outward current was accompanied by a fall in input resistance by $33 \pm 4 \%(n=17)$. Tolbutamide $(100-300 \mu \mathrm{M})$ inhibited the outward current by $67 \pm 8 \%(n=$ 7; Fig. $3 B$ ), and the fall in input resistance by $96 \pm 10 \%$. Glibenclamide $(30 \mu \mathrm{M})$ inhibited the diazoxide-induced current by $59 \pm 10 \%(n=9)$ and the fall in input resistance by $71 \pm$ $14 \%$. Tolbutamide $(300 \mu \mathrm{M})$ had no effect on holding current or input resistance when applied alone $(n-3)$.

\section{Effect of baclofen in comparison to that of diazoxide}

The effect of the GABA $\mathrm{B}_{\mathrm{B}}$ receptor agonist baclofen was compared to that of diazoxide in order to determine whether they activate the same set of potassium channels, as reported by Röper et al. (1990b). In contrast to diazoxide, which was effective in only $64 \%$ of neurons, bath application of baclofen (10-30 $\mu \mathrm{M}$ ) induced an outward current, or hyperpolarization, in all neurons tested $(n=21)$. The baclofen-induced outward current was also much more rapid in onset, and of larger amplitude, than that induced by diazoxide, taking only 1-2 min to reach a maximum of $140 \pm 13 \mathrm{pA}(n=13)$ or $12 \mathrm{mV}(n=2)$, under standard recording conditions (Fig. $3 C$ ), with a fall in input resistance of $49 \pm 4 \%$. In addition, the baclofen-induced current differed from that induced by diazoxide in that it was significantly larger in the presence of intracellular ADP and GDP (237 $\pm 41 \mathrm{pA}, n=6, p<0.05$ ). The effects of baclofen were fully reversed by washout for $25-30 \mathrm{~min}$ or by the $\mathrm{GABA}_{\mathrm{R}}$-receptor antagonist 2-hydroxy-saclofen (100-300 $\mu \mathrm{M}, n=3)$. In contrast, 2-hydroxy-saclofen $(300 \mu \mathrm{M})$ had no effect on the diazoxideinduced outward current $(n=3$; see rig. $3 B$ ). Also, tolbutamide $(100-300 \mu \mathrm{M})$ was without effect on the outward current induced by baclofen ( $n=4$; Fig. $3 C$ ).

Of 20 neurons to which both diazoxide and baclofen were applied sequentially (diazoxide applied first), 9 showed no response to diazoxide. For the 11 neurons that responded to both drugs, current-voltage plots were constructed using the instantaneous current responses evoked by voltage steps from a holding potential of $-65 \mathrm{mV}$. No reversal was apparent for the diazoxide-induced current in four of the neurons, despite the presence of an obvious reversal potential for baclofen in the same neurons (Fig. 4B). In the other seven neurons, the diazoxide-induced current reversed at $-93 \pm 4 \mathrm{mV}$, and the baclofeninduced current reversed at $-106 \pm 4 \mathrm{mV}\left(E_{\mathrm{K}}-108 \mathrm{mV}\right.$; Fig. $4 A$ ). In none of the neurons was the reversal potential for baclofen and diazoxide the same, and in six of the seven neurons the reversal potential for the diazoxide current was less negative than that for baclofen $(p<0.05)$.

The different reversal potentials obtained for diazoxide and baclofen indicate that they may be acting through different sets of ion channels, either (1) of different ionic permeability, or (2) of different location. This was investigated further by determining whether currents induced by maximally effective concentrations of the two drugs were additive (see North and Williams, 1985). Figure $5 A$ shows a neuron to which both baclofen and diazoxide were applied together, and is representative of four such experiments. The currents evoked by diazoxide and baclo- 
A

Control

Glucose-free

Wash
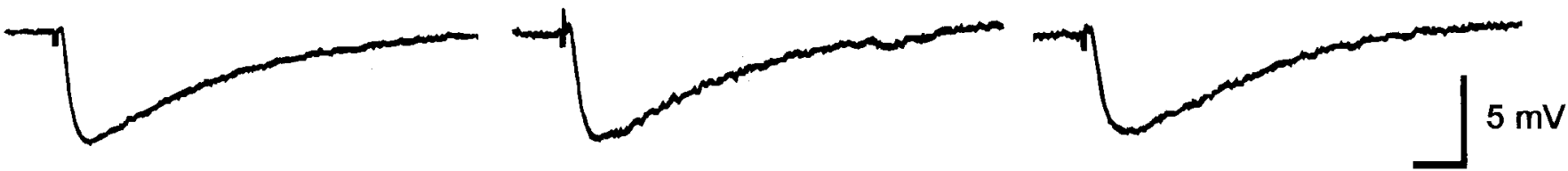

$20 \mathrm{~ms}$

B

Control Glucose-free

\section{Glucose-free} +Tolbutamide $300 \mu \mathrm{M}$

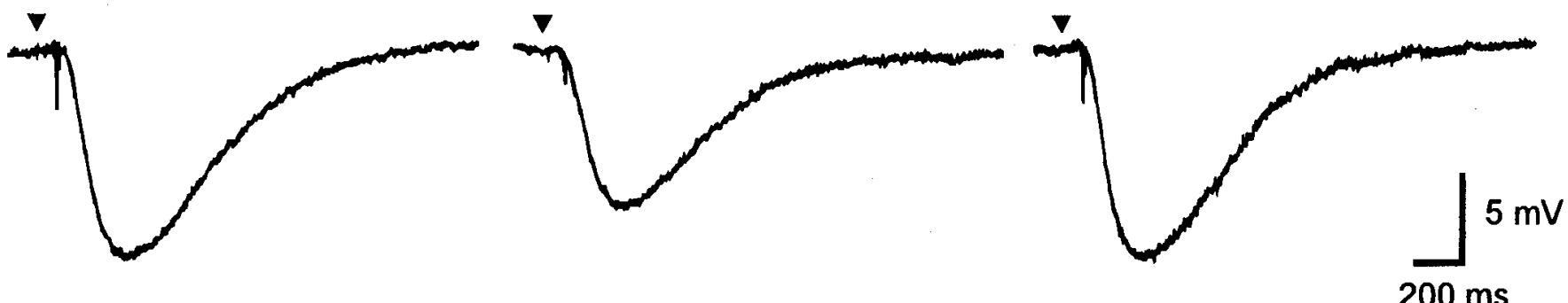

$200 \mathrm{~ms}$

C
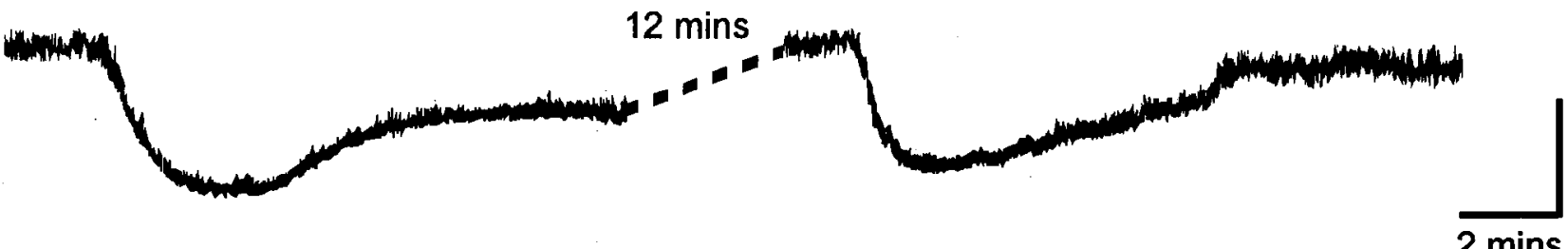

$10 \mathrm{mV}$

2 mins
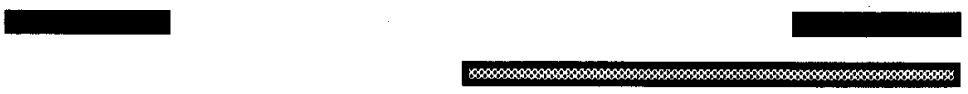

\section{Baclofen $10 \mu \mathrm{M}$ Glucose-free solution}

Figure 2. Glucose-free solutions inhibited the $\mathrm{GABA}_{\mathrm{B}}$, but not the $\mathrm{GABA}_{\mathrm{A}}$, IPSP. $A$, SN zona compacta neuron hyperpolarized to $-66 \mathrm{mV}$ with direct current injection. In the presence of CNQX $\left(10 \mu \mathrm{M}\right.$,) and AP5 $(30 \mu \mathrm{M})$, a single stimulus evoked a GABA A $_{\mathrm{A}}$-miated IPSP (left), which was unaffected by glucose-free solution $(20 \mathrm{~min}$; middle), and remained the same upon reapplication of glucose (right). $B$, In the presence of CNQX $(10 \mu \mathrm{M})$, AP5 $(30 \mu \mathrm{M})$, and bicuculline $(30 \mu \mathrm{M})$, a train of stimuli evoked a slow hyperpolarization (left). This GABA G $_{\mathrm{B}}$-mediated IPSP was reduced by $28 \%$ in glucose-free solution ( $20 \mathrm{~min}$; middle trace) an effect that was fully reversed by tolbutamide $(300 \mu \mathrm{M}$, right $)$. This neuron is representative of 6 of 12 neurons tested. In the other six neurons, the $\mathrm{GABA}_{\mathrm{B}}$ reduction was tolbutamide insensitive. Stimulus artifacts have been removed to allow a clear view of the IPSPs. Each trace is an average of four consecutive traces evoked in the same neuron. $C$, In a SN zona compacta neuron hyperpolarized to $-68 \mathrm{mV}$ with direct current injection $(-120 \mathrm{pA})$, a 3 min application of baclofen $(10 \mu \mathrm{M})$ induced an $11 \mathrm{mV}$ hyperpolarization. After bathing the slice in glucose-free solution for $15 \mathrm{~min},-80 \mathrm{pA}$ was required to hold the neuron at $-68 \mathrm{mV}$. The neuron again hyperpolarized $11 \mathrm{mV}$ in response to $10 \mu \mathrm{M}$ baclofen. Drugs were applied for the duration of the bars.

fen were additive. Following development of a maximum outward current with $500 \mu \mathrm{M}$ diazoxide (73 $\pm 19 \mathrm{pA}$ ), application of a maximally effective concentration of baclofen $(30 \mu \mathrm{M})$ induced a further current $(307 \pm 58 \mathrm{pA})$. The amplitude of the response to baclofen was $111 \pm 5 \%$ of the outward current induced by baclofen alone $33 \pm 2$ min later, following application of tolbutamide to remove any diazoxide response. The slightly smaller amplitude of response to the second application 


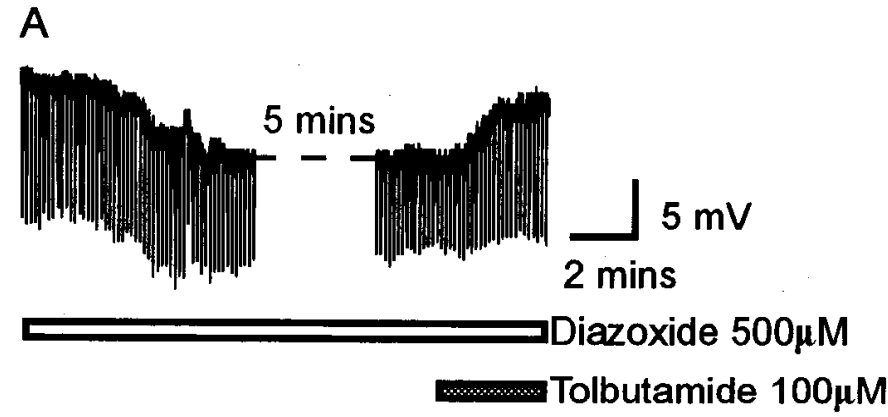

B

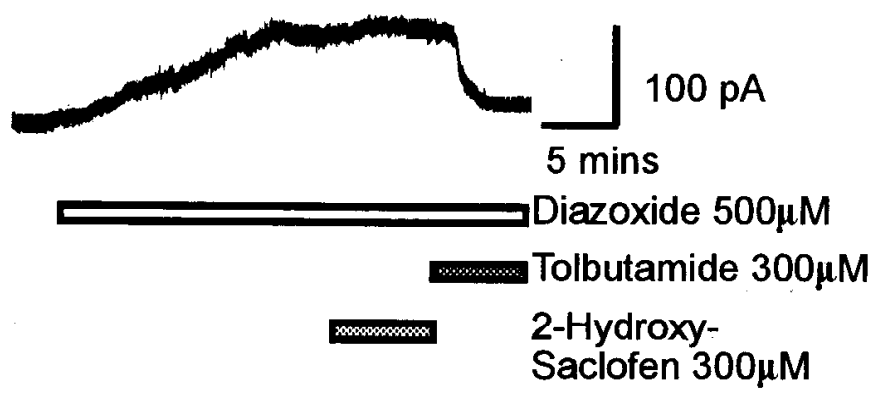

C

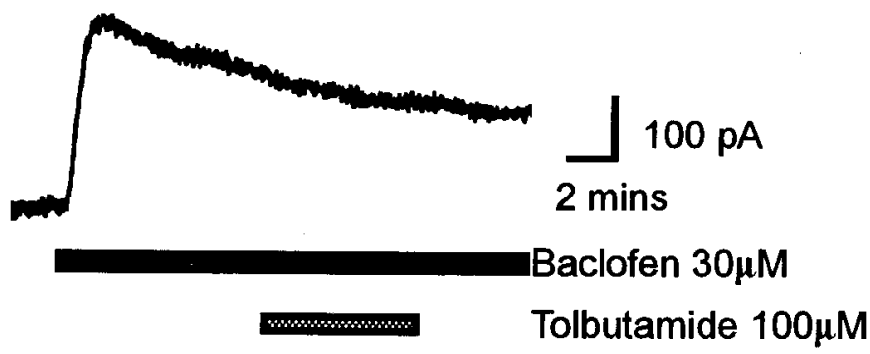

Figure 3. Diazoxide induced a hyperpolarization and outward current in SN principal neurons. $A$, A neuron hyperpolarized to $-65 \mathrm{mV}$ with direct current injection slowly hyperpolarized in response to diazoxide $(500 \mu \mathrm{M})$ and input resistance fell (measured from amplitude of membrane hyperpolarization to $100 \mathrm{msec}$ duration $-0.05 \mathrm{pA}$ pulses; downward deflections). The response to diazoxide was reversed by tolbutamide $(100 \mu \mathrm{M}) . B, \mathrm{SN}$ zona compacta neuron held at $-65 \mathrm{mV}$ in voltage clamp; a slowly developing outward current was induced by diazoxide $(500 \mu \mathrm{M})$, and was reversed by tolbutamide $(300 \mu \mathrm{M})$. The $\mathrm{GABA}_{\mathrm{B}}$-receptor antagonist 2-hydroxy-saclofen $(300 \mu \mathrm{M})$ was without effect on the diazoxide-induced outward current. $C$, A different neuron at $-65 \mathrm{mV}$ in voltage clamp; a rapidly developing outward current was induced by baclofen $(30 \mu \mathrm{M})$, which was insensitive to tolbutamide (100 $\mu \mathrm{M})$. There was a slow desensitization of the outward current in this neuron during prolonged baclofen application. Drugs were applied for the duration of the bars.

of baclofen is most likely due to receptor desensitization rather than any interaction with the diazoxide since, in another four cells, sequential applications of $30 \mu \mathrm{M}$ baclofen alone (35 \pm 3 min apart) revealed that the outward current induced by the first application of baclofen was $115 \pm 8 \%$ of the second response. These experiments demonstrate that the currents induced by ba- clofen and diazoxide are additive, and that the two drugs must be acting through different sets of channels.

Baclofen and other agonists of the superfamily of G-proteinlinked receptors activate a barium-sensitive inwardly rectifying potassium channel, $I_{K(\mathbb{R})}$ (Lacey et al., 1988; Williams et al., 1988; North, 1989). We investigated whether the diazoxide-activated current also showed barium-sensitivity by applying a low concentration of $\mathrm{Ba}^{2+}(300 \mu \mathrm{M})$. The baclofen-induced outward current was inhibited by $84 \pm 7 \%$ by application of $\mathrm{Ba}^{2+}(n=$ 3 ; Fig. $5 B$ ). The diazoxide-induced current was also sensitive, being inhibited by $76 \pm 3 \%$ in the presence of $\mathrm{Ba}^{2+}(300 \mu \mathrm{M}$, $n=4$ ).

The more positive reversal potential obtained with diazoxide than baclofen could indicate that diazoxide either (1) opens more than one type of channel, one of which is a potassium channel while the other may be selective for other ions, e.g., sodium, calcium, or (2) that the diazoxide-activated ATP-K ${ }^{+}$channel is not entirely selective for potassium ions over other cations. To investigate this further, we applied diazoxide to cells that had cesium as the major cation in the pipette solution instead of potassium. This should block potassium channels and reveal if diazoxide has an additional action. Of seven cells, five cells showed no change in holding current in response to diazoxide $(500 \mu \mathrm{M})$ or tolbutamide $(300 \mu \mathrm{M})$. The other two cells showed a slowly developing inward current $(-20 \mathrm{pA}$ and $-40 \mathrm{pA})$ in response to diazoxide, which was partially (50\% in each case) reversed by tolbutamide $(300 \mu \mathrm{M})$. Input resistance also fell (by $40 \%$ and $9 \%$ respectively), and was reversed (by $50 \%$ and $71 \%$ ) by tolbutamide.

\section{Discussion}

The present study demonstrates the synaptic input to dopaminergic neurons of the SN zona compacta to be mediated by excitatory amino acid (AMPA and NMDA) receptors, and GA$\mathrm{BA}_{\mathrm{A}}$ and $\mathrm{GABA}_{\mathrm{B}}$ receptors. This is in agreement with previous studies (Mereu et al., 1991, 1992; Johnson et al., 1992; Yung and Häusser, 1993). In contrast to the ${ }^{3} \mathrm{H}-\mathrm{GABA}$ release studies by Amorosso et al. (1990), our electrophysiological study showed no increase in the amplitude of either $\mathrm{GABA}_{\mathrm{A}^{-}}$or $\mathrm{GA}$ $\mathrm{BA}_{\mathrm{B}}$-mediated IPSPs with the ATP-K $\mathrm{K}^{+}$channel inhibitor glibenclamide. This finding may be interpreted in a number of ways: first, high-affinity ${ }^{3} \mathrm{H}$-glibenclamide binding sites located on striatonigral terminals (Hicks et al., 1994a) may indeed indicate the presence of functional ATP- $\mathrm{K}^{+}$channels, but the channels are closed in the presence of physiological levels of glucose and oxygen. The reduction in the amplitude of the $\mathrm{GABA}_{\mathrm{B}}$ receptormediated IPSP upon removal of glucose which, in a proportion of neurons was sulfonylurea reversible, indicates that functional $\mathrm{ATP}-\mathrm{K}^{+}$channels are, indeed, present on at least some nigral terminals. However, our results demonstrate that the slice must be metabolically compromised before such channels can open and subsequently be closed by the application of a sulfonylurea ATP- $\mathrm{K}^{+}$channel inhibitor. It appears that, under our recording conditions, there is sufficient ATP within the terminal to keep the channels closed. Second, it is possible that not all of the high-affinity ${ }^{3} \mathrm{H}$-glibenclamide binding sites on striatonigral terminals are coupled to ATP-K ${ }^{+}$channels. There is evidence that ATP- $\mathrm{K}^{+}$channels and sulfonylurea receptors can exist as independent proteins (Khan et al., 1993). Functional ATP-K ${ }^{+}$channels have been described in an insulinoma cell line that possessed no glibenclamide binding sites (Khan et al., 1993), and sulfonylurea drugs (including glibenclamide and tolbutamide) 
Baclofen $30 \mu \mathrm{M}$

A

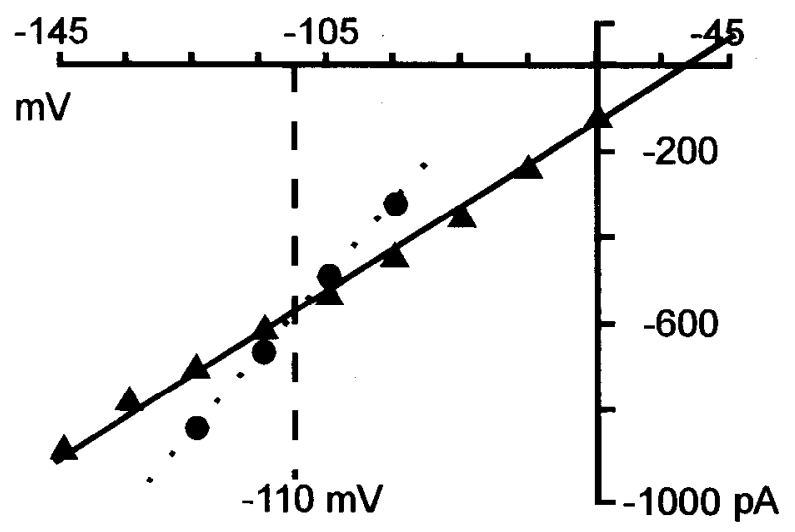

B

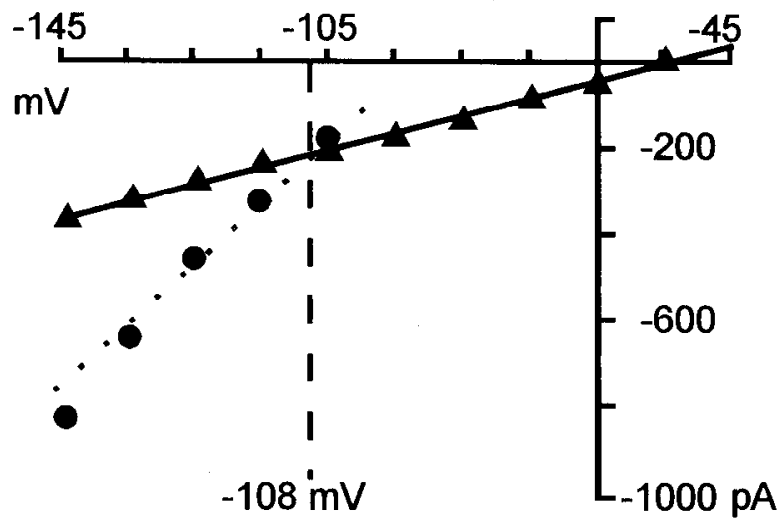

Diazoxide $500 \mu \mathrm{M}$
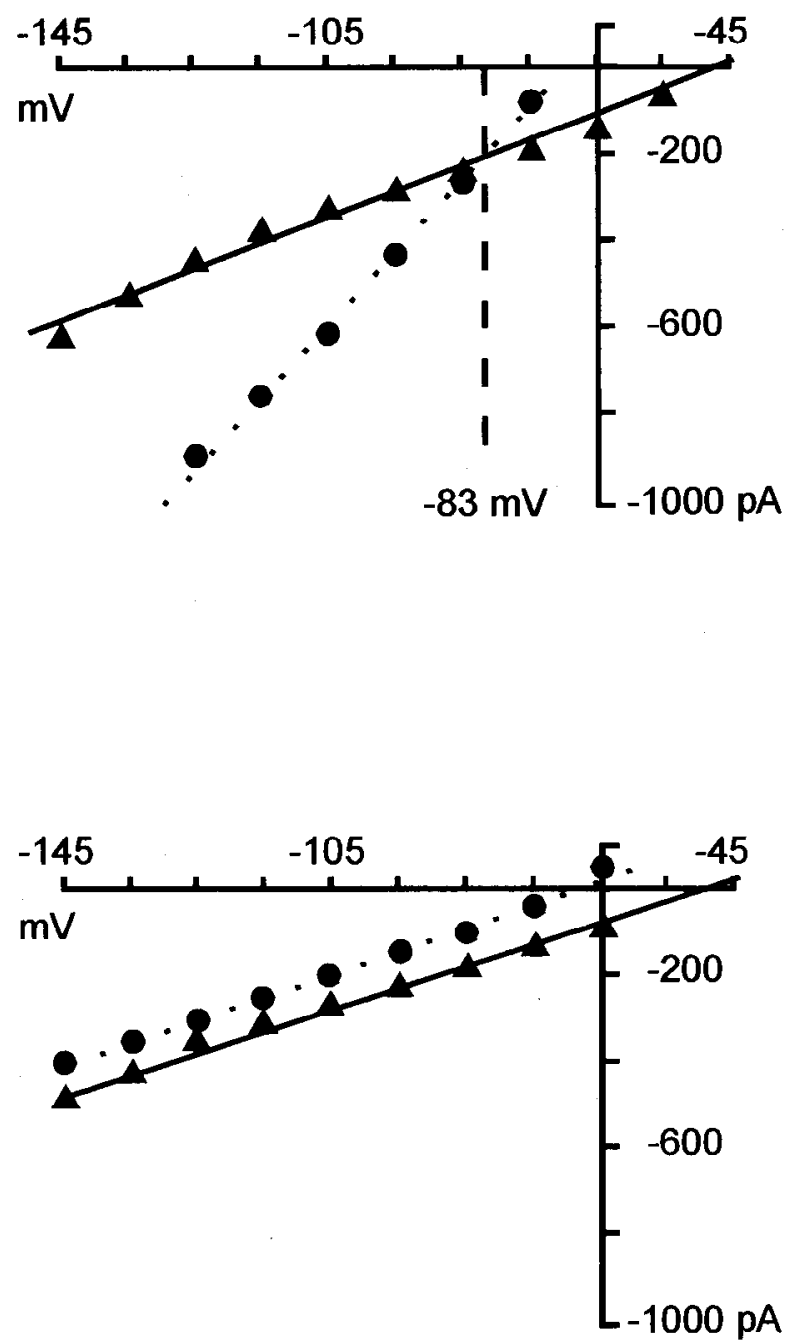

Figure 4. Diazoxide and baclofen activated outward currents with different reversal potentials. SN zona compacta neurons were held under voltage clamp at $-65 \mathrm{mV}$. Plots are of the instantaneous current evoked by voltage pulses to different membrane potentials between $-55 \mathrm{mV}$ and -145 $\mathrm{mV}$. This avoids any contamination by the slowly developing hyperpolarization-activated cation current, $\mathrm{I}_{\mathrm{h}}$, which is present in these neurons. The current at $-65 \mathrm{mV}$ is the holding current. $A$, Current-voltage relations for baclofen $(30 \mu \mathrm{M}$, left $)$ and diazoxide $(500 \mu \mathrm{M}$, right) in a single neuron; the reversal potential for diazoxide was $-83 \mathrm{mV}$. The reversal potential for baclofen was $-110 \mathrm{mV}$. This neuron is representative of 7 of 11 neurons that responded to both diazoxide and baclofen. $B$, Current-voltage relations for baclofen $(30 \mu \mathrm{M}$, left $)$ and diazoxide $(500 \mu \mathrm{M}$, right $)$ in another neuron. There was no intercept for the diazoxide-induced outward current, but an obvious reversal for that induced by baclofen $(-108 \mathrm{mV})$. This neuron is representative of 4 of 11 neurons that responded to both diazoxide and baclofen. Filled triangles are control; filled circles are at the maximum response to the drug.

have been shown to inhibit a voltage-dependent, ATP-independent potassium channel in hippocampal neurons (Crépel et al., 1993), and in a neuroblastoma cell line (Reeve et al., 1992).

We found that glucose-free solutions had a selective effect upon the $\mathrm{GABA}_{\mathrm{B}}$ receptor-mediated IPSP, leaving the $\mathrm{GABA}_{\mathrm{A}^{-}}$ mediated IPSP unaffected. It has been shown that synaptic inputs to $\mathrm{GABA}_{\mathrm{A}}$ and $\mathrm{GABA}_{\mathrm{B}}$ receptors in midbrain dopaminergic neurons originate from discrete afferent neurons (Johnson et al., 1992; Sugita et al., 1992). Long GABA-containing projection neurons from striatum preferentially release $\mathrm{GABA}$ onto GA$\mathrm{BA}_{\mathrm{B}}$ receptors, whereas $\mathrm{GABA}_{\mathrm{A}}$ synaptic potentials result from the activity of GABA-crgic ncurons intrinsic to the SN. Thus, our finding that only the $\mathrm{GABA}_{\mathrm{B}}$ receptor-mediated synaptic po- tential was affected by removal of glucose lends further support to the view that there are discrete inhibitory inputs onto $\mathrm{SN}$ zona compacta neurons that are under independent control.

Although the $\mathrm{GABA}_{\mathrm{B}}$-mediated IPSP was reduced in all neurons in glucose-free solutions, in half of neurons there was no recovery of the IPSP with tolbutamide. This would indicate that the reduction of the IPSP was not always mediated by the opening of sulfonylurea-sensitive ATP- $\mathrm{K}^{+}$channels. Others have reported that postsynaptic hyperpolarizations caused by anoxia in dopaminergic neurons are glibenclamide insensitive (Mercuri et al., 1994). These could be mediated by the "nonclassical" ATPscnsitive nonselective cation channcls (ATP-NS) that have becn described in cortical and cerebellar neurons (Ashford et al., 

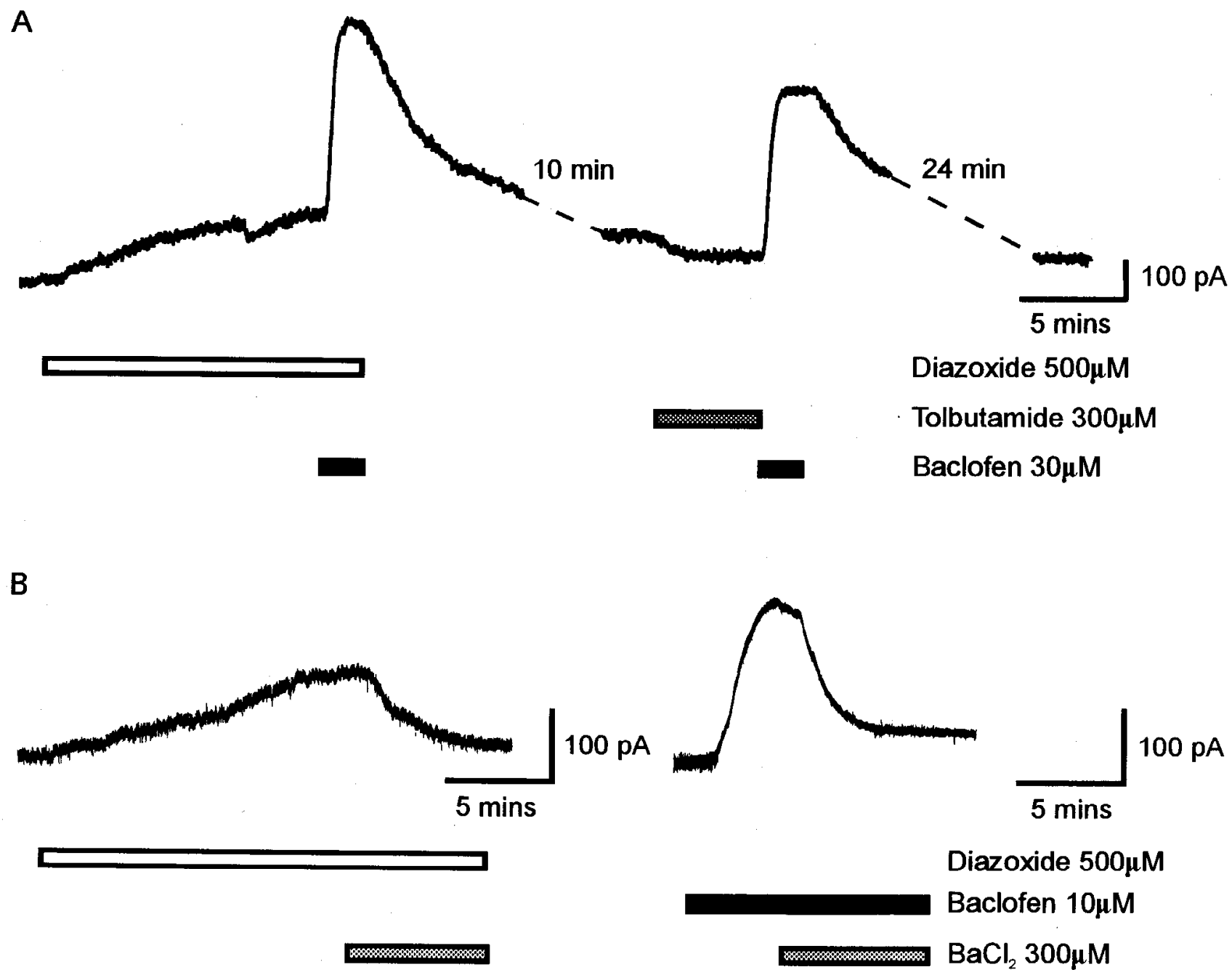

Figure 5. A, Diazoxide- and baclofen-induced currents were additive. Neuron held at $-65 \mathrm{mV}$ under voltage clamp. When baclofen (30 $\mu \mathrm{m})$ was applied in the presence of a steady-state outward current $(120 \mathrm{pA})$ in response to diazoxide $(500 \mu \mathrm{M})$, the amplitude of the baclofen-induced outward current was $390 \mathrm{pA}$. When baclofen was applied alone following inhibition of any diazoxide-sensitive current with tolbutamide (300 $\mu \mathrm{M}$ ), it induced an outward current of $350 \mathrm{pA}$. Drugs were applied for the duration of the bars. B. Diazoxide and baclofen both activated a bariumsensitive outward current. Neuron held at $-65 \mathrm{mV}$ under voltage clamp. Diazoxide $(500 \mu \mathrm{M})$. induced a slowly developing outward current of 110 pA that was reversed by $82 \%$ by $\mathrm{BaCl}_{2}(300 \mu \mathrm{M})$. In another neuron, also held at $-65 \mathrm{mV}$ under voltage clamp, baclofen $(10 \mu \mathrm{M})$ induced a rapidly developing outward current of $190 \mathrm{pA}$ that was reversed by $84 \%$ by $\mathrm{BaCl}_{2}(300 \mu \mathrm{M})$.

1988; Ohno-Shosaku and Yamamoto, 1992). Their sensitivity to sulfonylurea drugs was not reported.

SN zona compacta principal neurons hyperpolarize in response to diazoxide but not to another ATP-K ${ }^{+}$channel opener, levcromakalim, at concentrations up to $500 \mu \mathrm{M}$ (Hicks and Henderson, 1992; but see also Häusser et al., 1991). This difference may reflect a differential sensitivity to channel openers that has been described for other tissues (Edwards and Weston, 1993). SN zona compacta neurons would appear to have a similar pharmacology to the pancreatic $\beta$ cell, in which diazoxide $(100 \mu \mathrm{M})$ inhibited insulin release by more than $90 \%$ but levcromakalim $(500 \mu \mathrm{M})$ inhibited release by only $35 \%$ (see Edwards and Weston, 1993). Diazoxide produced an outward current in only a proportion of zona compacta principal neurons, in contrast to baclofen, which was effective in all neurons. The response to diazoxide was also variable, and was smaller than the baclofen response. This suggests that individual SN zona compacta neurons may exhibit differing levels of ATP-K $\mathrm{K}^{+}$channel expression, and that some neurons may not express ATP- $\mathrm{K}^{+}$channels at all.
Ohno-Shosaku and Yamamoto (1992) also found that diazoxide was ineffective in $50 \%$ of neurons in cultured rat neocortical and hippocampal neurons. Röper and Ashcroft (1993) did not report the percentage of $\mathrm{SN}$ neurons that responded to reduced intracellular ATP. An alternative explanation for the lack of response to diazoxide in some neurons is that it may not be able to activate all the ATP-K $\mathrm{K}^{+}$channels. For example, it may not be reaching its binding site on the intracellular side of the membrane in some neurons. We have attempted to apply diazoxide intracellularly by including it in the pipette solution at $100-500$ $\mu \mathrm{M}$. However, no outward current developed within 15-30 min of patch rupture, although subsequent bath application of 500 $\mu \mathrm{M}$ diazoxide to the same neuron did induce an outward current. The protocol has not been pursued due to the great difficulty in gaining recordings when diazoxide was included in the pipette.

Diazoxide has a pKa of 8.5 , so that during bath application at physiological $\mathrm{pH}$, more than $90 \%$ of the diazoxide applied is in the unionized, membrane permeable, form. Thus, it may be "mopped up" by the high level of lipid in brain tissue and, 
consequently, unable to reach more deeply located neurons. However, diazoxide was applied to the bath at a very high concentration $(500 \mu \mathrm{M})$. If diazoxide was reaching its site of action in all ncurons, then another possible explanation for the highly variable responses might be that the naturally high $(\mathrm{mM})$ levels of intracellular ATP in neurons inhibited the effect of diazoxide (Trube et al., 1986).

The inclusion of ADP and GDP in the pipette solution did not affect the response to diazoxide. This could indicate either that the diazoxide effect is independent of phosphorylation processes, or else an inability to dialyze ADP and GDP to distant parts of the dendritic tree. The baclofen-induced current was larger in the presence of ADP and GDP than in their absence, becoming similar in amplitude to that reported using "sharp" microelectrodes (Lacey et al., 1988). This indicates that ADP and GDP are required for full activation of the $G A B A_{B}$ receptoractivated channels, and that endogenous ADP and GDP were dialyzed out of at least the proximal part of the neuron during whole-cell recording when they were not included in the pipette solution.

In neurons that did respond to diazoxide, the reversal potential was found to be slightly less negative than that for the baclofeninduced current and the calculated $E_{\mathrm{K}}$ in these neurons. This indicates that the diazoxide-evoked current is either (1) through a channel that is not purely selective for potassium-possibly similar to the novel "nonclassical" ATP-sensitive nonselective cation channel (ATP-NS) described in cortical neurons (Ashford et al., 1988; Ohno-Shosaku and Yamamoto, 1992), or (2) diazoxide activates more than one type of channel in SN zona compacta neurons, each with a different reversal potential. These possibilities are not mutually exclusive. Diazoxide may open the "classical" ATP-K ${ }^{+}$channel, but may also open one or more other channels to some extent, such as the ATP-NS channel. Our experiments using cesium in the pipette provide support for the hypothesis that diazoxide opens more than one type of channel. The outward current induced by diazoxide was barium sensitive, showing that it was due to activation of the inward rectifying potassium channel. However, when potassium channels were blocked by intracellular cesium, diazoxide induced a small tolbutamide-sensitive inward current and fall in input resistance in a proportion of cells. 'The data do not provide conclusive evidence as to the ion(s) involved in this response but are consistent with the activation of an ATP-NS current. After prolonged glucose-free periods, neurons often suddenly went into a paroxysmal depolarization from which they sometimes recovered following reapplication of glucose (Watts and Hicks, unpublished observations). Neurons show a biphasic response to ischemia, hypoxia, or anoxia, with an initial hyperpolarization due to potassium channel activation followed by sudden depolarization due to nonselective ion movement (Hansen, 1985; Röper and Ashcroft, personal communication). Thus, it appears that ATPNS channels may well be present on these neurons, but that intracellular ATP levels must be exhausted before these channels open spontaneously.

Despite the similar sensitivity of the diazoxide- and baclofeninduced outward currents to blockade by $\mathrm{Ba}^{2+}$, the difference in their reversal potentials and the lack of effect of tolbutamide on the baclofen-induced current indicated that diazoxide and baclofen activated different sets of channels. Further investigation showed that the currents induced by diazoxide and baclofen were additive, strongly supporting this hypothesis. If the two drugs were activating the same potassium channels, then it would be expected that a maximally effective concentration of baclofen when applied in concert with diazoxide would induce a smaller current than when applied alone (North and Williams, 1985). Röper et al. (1990b) suggested that dopamine $D_{2}$ receptors and $\mathrm{GABA}_{\mathrm{B}}$ receptors activated $\mathrm{ATP}-\mathrm{K}^{+}$channels. However, we found no evidence for activation of $\mathrm{ATP}-\mathrm{K}^{+}$channels by dopamine (Hicks and Henderson, 1992), although a novel subtype of ATP-K $\mathrm{K}^{+}$channel recently described in corpus striatum may be modulated by quinpirole, an agonist at $D_{2}, D_{3}$, and $\mathrm{D}_{4}$ receptors (Lin et al., 1994). In the present study, we demonstrated that the diazoxide-activated channels are distinct from those opened by baclofen, and that the ATP- $\mathrm{K}^{+}$channel is not activated by the superfamily of inhibitory G-protein-linked receptors.

The striatonigral input has a major inhibitory influence on the $\mathrm{SN}$. Our results demonstrate that in times of metabolic stress, such as occurs in periods of anoxia and ischemia, ATP-K ${ }^{+}$channels on striatonigral terminals may become active due to reduced intraterminal levels of ATP. The resulting hyperpolarization of the terminal leads to a reduction of $G \wedge B \Lambda$ release. It is difficult to reconcile the disinhibition of $\mathrm{SN}$ zona compacta neurons that would result from the reduced GABA release, with the suppressant effects of ATP-K ${ }^{+}$channel activation postsynaptically. Perhaps a more subtle effect on dopaminergic neuron activity is afforded by the pre- and postsynaptic responses in concert. It is possible that the postsynaptic hyperpolarization required to prevent the damaging effects of anoxia and ischemia on the nigral neuron would lead to an upset of the normal interaction of these neurons with other CNS regions. By reducing the inhibitory synaptic input onto SN zona compacta neurons at this time, the neurons may be protected from damage while retaining a reasonably normal pattern of activity.

\section{References}

Amoroso S, Schmid-Antomarchi H, Fosset M, Lazdunski M (1990) Glucose, sulphonylureas and neurotransmitter release: role of ATPsensitive $\mathrm{K}^{+}$channels. Science 247:852-854.

Ashford MLJ, Sturgess NC, Trout NJ, Gardner NJ, Hales CN (1988) Adenosine-5'-triphosphate-sensitive ion channels in neonatal rat cultured central neurons. Pfluegers Arch 412:297-304.

Crépel V, Krnjévic K, Ben Ari Y (1993) Sulphonylureas reduce the slowly inactivating D-type outward current in rat hippocampal neurons. J Physiol (Lond) 466:39-54.

Edwards G, Weston AH (1993) The pharmacology of ATP-sensitive K-channels. Annu Rev Pharmacol Toxicol 33:597-637.

Hansen AJ (1985) Effect of anoxia on ion distribution in the brain. Physiol Rev 65:101-148.

Häusser MA, DeWeille JR, Lazdunski M (1991) Activation by cromakalim of pre- and post-synaptic ATP-sensitive $\mathrm{K}^{+}$channels in substantia nigra. Biochem Biophys Res Commun 174:909-914.

Hicks GA, Henderson G (1992) Lack of evidence for coupling of the dopamine $D_{2}$ receptor to an adenosine triphosphate-sensitive potassium channel in dopaminergic neurons of the rat substantia nigra. Neurosci Lett 141:213-217.

Hicks GA, Hudson AL, Henderson G (1994a) Localization of high affinity [ $\left.{ }^{3} \mathrm{II}\right]$-glibenclamide binding sites within the substantia nigra zona reticulata of the rat brain. Neuroscience 61:285-292.

Hicks GA, Watts AE, Henderson G (1994b) Synaptic potentials recorded in substantia nigra neurones: characterisation and modulation by ATP-sensitive potassium channels. Brain Res Assoc Abstr 11:65.

Johnson SW, Mercuri NB, North RA (1992) 5-Hydroxytryptamine receptors block the $\mathrm{GABA}_{B}$ synaptic potential in rat dopamine neurones. J Neurosci 12:2000-2006.

Khan RN, Hales CN, Ozanne SE, Odogu AA, Ashford MLJ (1993) Dissociation of KATP channel and sulphonylurea receptor in the rat clonal insulin secreting cell line CRI-D11. Proc R Soc Lond [Biol] 253:225-231.

Lacey MG, Mercuri NB, North RA (1988) On the potassium conduc- 
tance increase activated by GABA $A_{B}$ and dopamine $D_{2}$ receptors in rat substantia nigra neurones. J Physiol (Lond) 401:437-453.

Lacey MG, Mercuri NB, North RA (1989) Two cell types in rat substantia nigra zona compacta distinguished by membrane properties and the action of dopamine and opioids. J Neurosci 9:1233-1241

Lee K, Ozanne SE, Hales CN, Ashford MLJ (1994) $\mathrm{Mg}^{2+}$-dependent inhibition of $\mathrm{K}_{\mathrm{ATP}}$ by sulphonylureas in CRI-G1 insulin-secreting cells. Br J Pharmacol 111:632-640.

Lin Y-J, Greif GJ, Freedman JE (1994) Multiple sulphonylurea-sensitive potassium channels: a novel subtype modulated by dopamine. Mol Pharmacol 44:907-910.

Mercuri NB, Bonci A, Johnson SW, Stratta F, Calabresi P, Bernardi G (1994) Effects of anoxia on rat midbrain dopamine neurones. J Neurophysiol 71:1165-1173.

Mereu G, Costa E, Armstrong DM, Vicini S (1991) Glutamate receptor subtypes mediate excitatory synaptic currents of dopamine neurones in midbrain slices. J Neurosci 11:1359-366.

Mereu G, Costa E, Livesy CT, Vicini S (1992) Modulation of GABA $A_{A}^{-}$ gated $\mathrm{Cl}^{-}$currents in nigral neurones in slices. In: GABA-ergic synaptic transmission (Biggio G, Concas A, Costa E, eds), pp 179-188. New York: Raven.

Mourre C, Ben Ari Y, Bernardi H, Fosset M, Lazdunski M (1989) Antidiabetic sulphonylureas: localization of binding sites in the brain and effects on the hyperpolarisation induced by anoxia in hippocampal slices. Brain Res 486:159-164.

Mourre C, Widmann C, Lazdunski M (1990) Sulphonylurea binding sites associated with ATP-regulated $\mathrm{K}^{+}$channels in the central nervous system: autoradiographic analysis of their distribution and ontogenesis, and of their localization in mutant mice cerebellum. Brain Res 519:29-43.

Nedergaard S, Greenfield SA (1992) Sub-populations of pars compacta neurones in the substantia nigra: the significance of qualitatively and quantitatively distinct conductances. Neuroscience 48:423-437.

North RA (1989) Drug receptors and the inhibition of nerve cells. $\mathrm{Br}$ J Pharmacol 98:13-28.

North RA, Williams JT (1985) On the potassium conductance increased by opioids in rat locus coeruleus neurones. J Physiol (Lond) 364:265-280

Ohno-Shosaku T, Yamamoto C (1992) Identification of an ATP-sensitive $\mathrm{K}^{+}$channel in rat cultured cortical neurons. Pfluegers Arch 422: 2600-266.

Reeve HL, Vaughan PFT, Peers C (1992) Glibenclamide inhibits a voltage-gated $\mathrm{K}^{+}$current in the human neuroblastoma cell line $\mathrm{SH}$ SY5Y. Neurosci Lett 135:37-40.

Röper J, Ashcroft FM (1993) Reduced internal ATP concentrations and mitochondrial inhibition activate $\mathrm{K}^{+}$-ATP channels in isolated dopaminergic substantia nigra neurones from rat. J Physiol (Lond) 473 : 33P.

Röper J, Hainsworth AH, Ashcroft FM (1990a) ATP-sensitive K channels in guinea-pig isolated substantia nigra neurones are modulated by cellular metabolism. J Physiol (Lond) 430:130P.

Röper J, Hainsworth AH, Ashcroft FM (1990b) Tolbutamide reverses membrane hyperpolarisation induced by activation of $\mathrm{D}^{2}$ receptors and $\mathrm{GABA}_{\mathrm{B}}$ receptors in isolated substantia nigra neurones. Pfluegers Arch 416:473-475.

Schmid-Antomarchi H, Amoroso S, Fosset M, Lazdunski M (1990) $\mathrm{K}^{+}$ channel openers activate brain sulphonylurea-sensitive $\mathrm{K}^{+}$channels and block neurosecretion. Proc Natl Acad Sci USA 87:3489-3492.

Schwanstecher C, Panten U (1993) Tolbutamide and diazoxide-sensitive $\mathrm{K}^{+}$channel in neurons of substantia nigra pars reticulata. Naunyn Schmiedebergs Arch Pharmacol 348:113-117.

Schwanstecher M, Löser S, Rietze L, Panten U (1991) Phosphate and thiophosphate group donating adenine and guanine nucleotides inhibit glibenclamide binding to membranes from pancreatic islets. Naunyn Schmiedebergs Arch Pharmacol 343:83-89.

Sugita S, Johnson SW, North RA (1992) Synaptic inputs to GABA and $G A B A_{B}$ receptors originate from discrete afferent neurones. Neurosci Lett 134:207-211.

Terzic A, Tung RT, Inanobe A, Katada T, Kurachi Y (1994) G proteins activate ATP-sensitive $\mathrm{K}^{+}$channels by antagonising ATP-dependent gating. Neuron 12:885-893.

Treherne JM. Ashford MLJ (1991) The regional distribution of sulphonylurea binding sites in rat brain. Neuroscience 40:523-531.

Trube G, Rorsman P, Ohno-Shosaku T (1986) Opposite effects of tolbutamide and diazoxide on the ATP-dependent $\mathrm{K}^{+}$channel in mouse pancreatic $\beta$ cells. Pfluegers Arch 407:493-499.

Watts AE, Hicks GA, Henderson G (1994) Diazoxide induces a sulphonylurea sensitive outward current in rat substantia nigra zona compacta neurones in vitro. J Physiol (Lond) 475:146P.

Williams JT, North RA, Tokimasa T (1988) Inward rectification of resting and opiate-activated potassium currents in rat locus coeruleus neurons. J Neurosci 8:4299-4306.

Yung WH, Häusser MA (1993) Evoked and spontaneous inhibitory postsynaptic potentials in guinea-pig substantia nigra neurones in vitro. J Physiol (Lond) 459:431P.

Yung WH, Häusser MA, Jack JJB (1991) Electrophysiology of dopaminergic and non-dopaminergic neurones of the guinea-pig substantia nigra pars compacta in vitro. J Physiol (Lond) 436:643-667.

Zini S, Zini R, Ben-Ari Y (1993) Nucleotides modulate the low affinity binding sites for $\left[{ }^{3} \mathrm{H}\right]$-Glibenclamide in the rat brain. J Pharmacol Exp Ther 264:701-708. 